TÀI LIÊU THAM KHẢO

1. Al-Omiri, M.K.; Mahmoud, A.A.; Rayyan, M.R.; Abu-Hammad, $O$. Fracture resistance of teeth restored with post-retained restorations: an overview. Journal of endodontics 2010, 36, 1439-1449.

2. Bjørndal, L.; Reit, C. Endodontic malpractice claims in Denmark 1995-2004. International endodontic journal 2008, 41, 1059-1065.

3. Aguilar, P.; Linsuwanont, P. Vital pulp therapy in vital permanent teeth with cariously exposed pulp: a systematic review. Journal of endodontics 2011, 37, 581-587.

4. Matsuo T, Nakanishi T, Shimizu H, Ebisu S. A clinical study of direct pulp capping applied to carious-exposed pulps. J Endod 1996;22:551-6.

5. Tran, X.V.; Gorin, C.; Willig, C.; Baroukh, B.; Pellat, B.; Decup, F.; Opsahl Vital, S.; Chaussain, C.; Boukpessi, T. Effect of a calcium- silicate-based restorative cement on pulp repair. Journal of dental research 2012,91, 1166-1171.

6. Pradelle-Plasse, N.; Tran, X.V.; Colon, P.; Laurent, P.; Aubut, V.; About, I.; Goldberg, M. Emerging trends in (bio) material research. Biocompatibility or Cytotoxic Effects of Dental Composites, 1st ed. Oxford, UK: Coxmoor Publishing Company 2009, 181-203.

7. Tran, X.V.; Salehi, H.; Truong, M.T.; Sandra, M.; Sadoine, J.; Jacquot, B.; Cuisinier, F.; Chaussain, C.; Boukpessi, T. Reparative mineralized tissue characterization after direct pulp capping with calcium-silicate-based cements. Materials 2019, 12, 2102.

8. Ricucci, D.; Loghin, S.; Siqueira Jr, J.F. Correlation between clinical and histologic pulp diagnoses. Journal of endodontics 2014, 40, 1932-1939.

\title{
KẾT QUẢ HÓA TRỊ BỔ TRỢ TRƯớC PHÁC ĐỒ 4AC-4T Ở BỆNH NHÂN UNG THƯ VÚ GIAI ĐOẠN TIẾN TRIỂN TẠI CHỖ
}

\section{TÓM TẮT}

Mục tiêu: Mô tả một số đặc điểm lâm sàng, cận lâm sàng của bênh nhân ung thư vú (UTV) giai đoạn tiến triển tại chỗ và đánh giá kết quả hoá trị bổ trợ trước phác đồ $4 A C-4 T$ và tác dụng không mong muốn ở nhóm bệnh nhân $(B N)$ trên. Đối tượng và phương pháp nghiên cứu: Nghiên cứu mô tả cắt ngang hồi cứu trên 52 BN UTV giai đợn tiến triển tại chỗ được hóa tri bổ trơ trước phấu thuât phác đồ $4 A C-4 T$ (Docetacel) tại bệnh viện K3. Kết quả: Đặc điểm nhóm nghiên cứu: Tuổi trung bình BN: 49,6 tuổi, phần lớn BN ở giai đoạn III $(96,1 \%)$ trong khi 3,9\% BN ở giai đoan IIB, 96,2\% BN có thể mô bênh học là ung thư biểu mô xâm nhập típ NST, đa sổ BN có độ mô học II $(73,1 \%)$. Đáp ứng: Sau điêu trị hóa chất, tî lệ người bệnh đáp ứng hoàn toàn (ĐƯHT) trên lâm sàng tăng từ $5,8 \%$ sau 4 đợt hóa trị lên $26,9 \%$ sau 8 đợt hóa trị. Có 1 BN tiến triển lâm sàng sau điêuu trị 8 chu kỳ hóa chất. Cả 52 BN đều được phẫu thuật sau hóa trị. ĐƯ'HT trên mô bệnh học đạt 28,8\%. Độc tính: BN trong nghiên cứu dung nạp khá tốt với phác đồ hóa chất. Tî lệ hạ bạch câu và hạ bạch câu đa nhân trung tính thường gặp độ 1,2. Tỉ lệ hạ bạch câu độ 3,4 trên tổng số chu kỳ hóa chất là $6,7 \%$ và $1,2 \%$. Nôn, chán ăn là những tác dụng không mong muốn thường gặp khi điều trị, tuy nhiên chỉ ở độ 1 và độ 2 . Rụng tóc gặp ở tất cả các $B N$, phân lớn là rụng gân hết hoặc

\section{${ }^{1}$ Trường Đại học Y Hà Nội \\ ${ }^{2}$ Bệnh viện $K$ \\ ${ }^{3}$ Bềnh viền Bach Mai}

Chịu trách nhiệm chính: Nguyễn Thị Phương Thảo

Email: thaophuong2705@gmail.com

Ngày nhận bài: 15.4.2021

Ngày phản biên khoa học: 28.5.2021

Ngày duyệt bài: 15.6.2021 toàn bộ. Kết luận: Phác đồ 4AC-4Docetacel được chứng minh có hiệu quả, độc tính của phác đồ chẩp nhận được, do vậy có thể áp dụng trong điều trị bổ trợ trước phẫu thuật UTV giai đoạn tiến triển tại chỗ trong điều kiện hiện nay ở nước ta.

Tư khóa: Ung thư vú giai đoạn tiến triển tại chỗ, điều trị bổ trợ trước, phác đồ 4AC-4Docetacel.

\section{SUMMARY \\ EFFICACY OF NEOADJUVANT 4AC-4T REGIMENT IN LOCALLY ADVANCED BREAST CANCER}

Objectives: Our study aims to describe the clinical and paraclinical characteristics of locally advanced breast cancer patients and evaluate the treatment outcomes and toxicity of neoadjuvant 4AC4T regiments in this group. Patients and Methods: Retrospective, descriptive study on 52 patients with locally advancer breast cancer, were treated with neoadjuvant 4AC-4T regiment at National Cancer Hospital. Results: The mean age was 49,6 . The majority of them were in stage III $(96,1 \%)$ while $3,9 \%$ patients were in stage IIB. $96,2 \%$ patients's histology were invasive carcinoma of no special type (NST) and $73,1 \%$ was in grade II. After treatment, the complete clinical response rised from 5,8\% (after 4 cycles of AC) to $26,9 \%$ (after 8 cycles of $4 A C$ 4Docetacel). There was 1 patients progressed during 4 docetacel cycles. All of our patients were moved to modified radical mastectomy after neoadjuvant chemotherapy. The pathological complete response (pCR) rate was $28,8 \%$. Most adverse events were manageable and tolerable. The most common toxicity was neutropenia with grade 1,2 . Non hematological toxicities such as vomiting, fatigue and alopecia were also common and all of them were mild and moderate. Conclusion: In locally advanced breast 
cancer patients, 4AC-4Docetacel regiment in neoadjuvant setting is effective with tolerable tocxicity, therefore this regiment can be widely used as neoadjuvant chemotherapy prior to surgery in our country.

Keywords: Locally advanced breast cancer, Neoadjuvant chemotherapy, 4AC-4Docetacel regiment

\section{I. ĐĂT VẤN ĐỀ}

Ung thư vú (UTV) là loại ung thư phổ biến nhất và là nguyên nhân gây tử vong hàng đầu do ung thư ở phụ nữ trên thế giới ${ }^{1}$. Tại Việt Nam UTV đứng hàng số 1 ở nữ, số ca mắc mới là 15.229 (chiếm 20,6\% số ca ung thư mới mắc ở phụ nữ), số ca tử vong là 6.103 trường hợp (đứng hàng thứ 4 trong số các bệnh ung thư của cả 2 giới) $)^{2}$. BN UTV giai đoan tiến triển tai chỗ bao gồm những $\mathrm{BN}$ có khối u nguyên phát lớn $(>5 \mathrm{~cm})$ hoặc u với mọi kích thước xâm lấn thành ngực hoặc xâm lấn da và/hoăc di căn hạch vùng trên lâm sàng được định nghĩa là hạch N2 hoăc N3 (giai đoạn IIB (T3N0) hoặc III theo phân loại $\mathrm{AJCC}$ bản 8$)^{3,4}$. Nhóm $\mathrm{BN}$ này thường không mổ được ngay, càng không thể phẫu thuật bảo tồn, và bởi vì nguy cơ tái phát xa yêu cầu điều trị hế thống. Vì vậy điều trị hóa chất bổ trợ trước cho nhóm này trở thành điều trị tiêu chuẩn, giúp làm giảm giai đoạn bệnh, làm tăng tỉ lệ từ không mổ được thành mổ được và đối với những khối u có thể mổ được cho phép tăng tỉ lệ phẫu thuật bảo tồn. Phác đồ $4 \mathrm{AC}-4 \mathrm{~T}$ được sử dụng rộng rã்i trên thế giới. Tuy nhiên, các nghiên cứu đánh giá hiệu quả hóa chất bổ trợ trước phác đồ $\mathrm{AC}-\mathrm{T}$ mà cụ thể là $4 A C$ - 4Docetacel trong UTV giai đoạn tiến triển tại chỗ ở Việt Nam còn ít, vì vậy, chúng tôi tiến hành đề tài nghiên cứu này với 2 mục tiêu:

1. Mô tả mốt số đặc điểm lâm sàng, cận lâm sàng của bệnh nhân ung thư vú giai đoạn tiến triển tại chố.

2. Đánh giá kêt quả hoá tri bổ trơ trước phác đồ $4 A C-4 T$ và tác dung không mong muốn ở nhóm bệnh nhân trên.

\section{II. ĐỐI TƯỢNG VÀ PHƯƠNG PHÁP NGHIÊN CỨU}

2.1. Đối tượng nghiên cứu: Gồm 52 bênh nhân UTV giai đoạn tiến triển tại chỗ được hóa trị bổ trợ trước phác đồ 4AC-4Docetacel tại Bệnh viện K3 từ tháng 1 năm 2018 đến tháng 6 năm 2020.

\section{Tiêu chuẩn lựa chon bênh nhân:}

- Tất cả BN được chẩn đoán xác định là ung thư biểu mô tuyến vú với chẩn đoán lâm sàng giai đoạn IIB (T3N0) và III theo tiêu chuẩn AJCC phiên bản 8 .

- Chưa được điều trị đặc hiệu gì về bệnh UTV trước hóa chất tân bổ trợ.
- Chỉ số toàn trạng $\leq$ 2theo thang điểm ECOG

- Không có chống chỉ định với các thuốc nhóm Anthracyclin: các bệnh lý tim mạch nặng như suy tim, viêm cơ tim, nhồi máu cở tim, ..., được siêu âm tim trước có tỉ số tống máu thất trái $\geq 55 \%$

- Bilan huyết học, gan, thận đủ điều kiện để $\mathrm{BN}$ điều trị hóa chất.

- Có đầy đủ hồ sơ lưu trữ, có đầy đủ thông tin về tình trạng bệnh.

\section{Tiêu chuân loại trừ:}

- UTV không xểp loại giai đoạn được.

- Ung thư từ nơi khác di căn đến vú

- UTV tái phát sau điều trị bảo tổn

- Bệnh nhân đang mang thai

Không có hồ sơ lưu trữ, hoặc hồ sơ không đủ các thông tin cần thiết

\subsection{Phương pháp nghiên cứu:}

Thiết kế nghiên cứu: nghiên cứu mô tả cắt ngang hồi cứu

\subsection{Các bước tiến hành}

Bước 1: Lựa chọn, đánh giá bệnh nhân theo đúng các tiêu chuẩn lựa chọn

Bước 2: Thu thập thông tin:

Đặc điểm bệnh nhân trước điều trị:

- Tuổi

- Đặc điểm khối u nguyên phát và hạch: kích thước, vị trí, số lượng, tính chất, ...

- Giải phẫu bệnh, hóa mô miễn dịch,...

Hóa trị bổ trợ trước phẫu thuật: Phác đồ 4AC4T bao gồm:

- 4 chu kỳ hóa chất AC: Doxorubicin $60 \mathrm{mg} / \mathrm{m}^{2}$, Cyclophosphamide $600 \mathrm{mg} / \mathrm{m}^{2}$ và 4 chu kỳ sau dùng Docetacel $75 \mathrm{mg} / \mathrm{m}^{2}$. Chu kỳ 21 ngày.

- Dự phòng hạ bạch cầu khi sử dụng Docetacel: Filgrastim $300 \mu \mathrm{g} /$ ngày sau khi kết thúc Docetacel 24-72h trong 3-5 ngày.

- Đánh giá lại sau 4 và 8 chu kỳ hóa chất: khám lâm sàng, siêu âm tuyến vú chụp xquang phổi, siêu âm ổ bụng, siêu âm tim.

\section{Đánh giá đáp ứng:}

- Đáp ứng lâm sàng theo "Tiêu chuẩn đánh giá đáp ứng cho khối đặc" - RECIST $1.1^{5}$

- Đáp ứng mô bệnh học: đánh giá đáp ứng mô bệnh học sau phẫu thuật theo phân loại Chevallier ${ }^{6}$

- Tỉ lệ BN chuyển từ không mổ được sang mổ được, tỉ lệ phẫu thuật bảo tồn.

- Đốc tính điêu trị: theo tiêu chuẩn CTCAE phiên bản số 4.0 của viện Ung thư quốc gia Mỹ (NCI- National Cancer Institute)

\section{KẾT QUẢ NGHIÊN CỨU}

\section{1. Đặc điểm bệnh nhân}




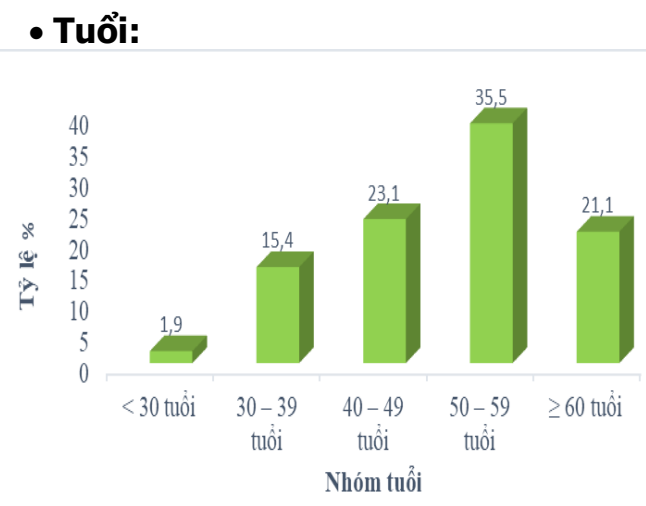

Biểu đồ 3.1. Phân bố tuổi bệnh nhân trong nghiên cứu

Nhận xét: Đa số người bệnh tham gia nghiên cứu có độ tuổi từ 50-59tuổi, chiếm $38.5 \%$. Độ tuổi trung bình là 49,6 $\pm 9,6$ tuổi, BN có tuổi nhỏ nhất là 28 tuổi và $B N$ có tuổi lớn nhất là 68 tuổi.

- Giai đoan bênh

Bảng 3.1. Giai đoạn bệnh

\begin{tabular}{|c|c|c|}
\hline Giai đoạn & Số lượng (n) & Tỷ lệ (\%) \\
\hline IIB & 2 & 3,9 \\
\hline IIIA & 36 & 69,2 \\
\hline IIIB & 9 & 17,3 \\
\hline IIIC & 5 & 9,6 \\
\hline Tống & 52 & 100 \\
\hline
\end{tabular}

Nhận xét: Phần lớn người bệnh ở giai đoạn III (chiếm 96,1\%). Chỉ có 3,9\% người bệnh ở giai đoan IIB.

- Thể bệnh học theo St. Gallen 2013

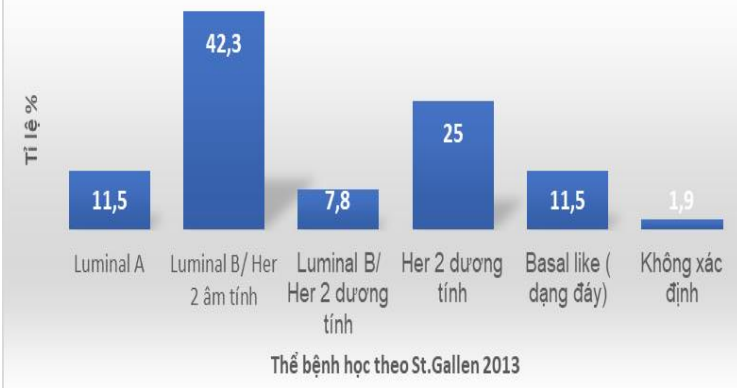

Biểu đồ 3.3. Thể bệnh học theo St. Gallen $2013(n=52)$

- Đặc điểm mô bênh học

Bảng 3.2. Đặc điểm mồ bênh học $(n=52)$

\begin{tabular}{|c|c|c|c|}
\hline \multicolumn{2}{|c|}{ Đặc điểm } & $\begin{array}{c}\text { Số lượng } \\
\text { (n) }\end{array}$ & $\begin{array}{l}\text { Tý lế } \\
(\%)\end{array}$ \\
\hline $\begin{array}{l}\text { Loại } \\
\text { mố }\end{array}$ & $\begin{array}{c}\text { UTBM xâm nhập típ } \\
\text { NST }\end{array}$ & 50 & 96 \\
\hline $\begin{array}{l}\text { bệnh } \\
\text { học }\end{array}$ & $\begin{array}{c}\text { Ung thư thế tiếu thùy } \\
\text { xâm nhập }\end{array}$ & 1 & 1,9 \\
\hline
\end{tabular}

\begin{tabular}{|c|c|c|c|}
\hline & $\begin{array}{c}\text { UTBM xâm nhập thế } \\
\text { dị sản vảy }\end{array}$ & 1 & 1,9 \\
\hline \multirow{2}{*}{$\begin{array}{c}\text { Độ mô } \\
\text { học }\end{array}$} & I & 6 & 11,5 \\
\cline { 2 - 4 } & II & 38 & 73,1 \\
\cline { 2 - 4 } & III & 8 & 16,4 \\
\hline
\end{tabular}

Nhận xét: Thể mô bệnh học hay gặp nhất là carcinoma xâm nhâp típ NST chiếm 96,2\%. Đa số người bệnh có độ mô học II, chiếm 73,1\%.

3.2. Đánh giá kết quả và một số tác dụng không mong muốn của phác đồ

3.2.1. Đáp ứng

- Đáp ứng lâm sàng

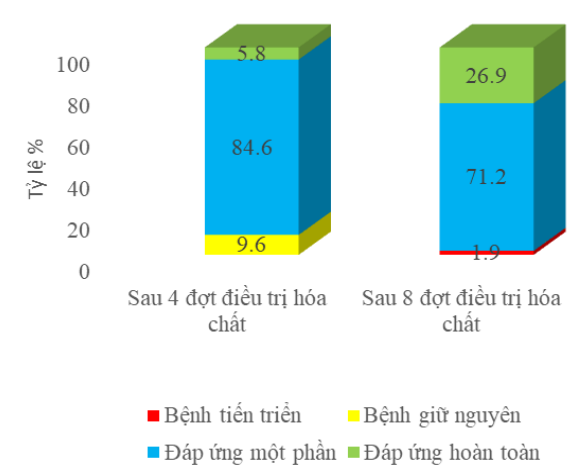

Biểu đồ 3.4: Đáp ứng lâm sàng sau điều trị hóa chất $(n=52)$

Nhận xét: Sau điều trị hóa chất, tỉ lệ người bênh ĐƯHT tăng từ 5,8\% sau 4 đợt điều trị hóa chất lên $26,9 \%$ sau 8 đợt điều trị hóa chất. Có 1 BN tiến triển sau điều trị 8 chu kỳ hóa chất.

- Đáp ứng mô bệnh học

Bảng 3.3: Kêt quả đáp ứng mô bệnh học theo Chevallier

\begin{tabular}{|c|c|c|}
\hline $\begin{array}{c}\text { Đáp ứng theo phân loại } \\
\text { Chevallier }\end{array}$ & $\mathbf{n}$ & $\%$ \\
\hline $\begin{array}{c}\text { Nhóm 1: biến mất hoàn toàn tế } \\
\text { bào ung thư }\end{array}$ & 11 & 21,2 \\
\hline $\begin{array}{c}\text { Nhóm 2: biểu hiện của UTBM tại } \\
\text { chố }\end{array}$ & 4 & 7,6 \\
\hline $\begin{array}{c}\text { Nhóm 3: còn UTBM xâm nhập, có } \\
\text { biến đổi hoại tử, xơ hóa }\end{array}$ & 35 & 65,4 \\
\hline Nhóm 4: có ít thay đối diện mạo u & 2 & 3,8 \\
\hline Tống & 52 & 100 \\
\hline
\end{tabular}

Nhận xét: có 11 người bệnh hoàn toàn không còn tổ chức ung thư trên bệnh phẩm u vú và hạch nách (chiếm 21,2\%), có 4 người bệnh còn tổ chức ung thư tại chỗ (chiếm 7,6\%). Tỷ lệ đạt $\mathrm{pCR}$ (nhóm 1 và nhóm 2 theo Chevallier) là $28,8 \%$.

- Tỷ lệ chuyển mổ: Trong nghiên cứu của chúng tôi có 52 BN đều được phẫu thuâtt, trong đó tất cả các bệnh nhân đều được phẫu thuật cắt tuyến vú triệt căn biến đổi. 


\subsubsection{Một số tác dụng không mong muốn của phác đồ \\ - Trên hệ huyết học: Tỉ lệ hạ bạch cầu và} bạch cầu đa nhân trung tính thường gặp là độ 1,2. Hạ bạch câu đa nhân trung tính độ 3,4 là 6,7 và $1,2 \%$ trên tổng số 415 chu kỳ. Độc tính hạ huyết sắc tố cũng thường gặp ở độ 1 .

- Ngoài hệ huyết học: Nôn, chán ăn là những tác dụng không mong muốn thường gặp khi điêu trị, tuy nhiên chỉ ở độ 1 và độ 2 . Rụng tóc gặp ở tất cả các bệnh nhẩn, phần lớn bệnh nhân rụng gần hết hoặc toàn bộ.

\section{BÀN LUÂN}

\section{Đặc điểm của nhóm nghiên cứu}

Tuổi: Tuổi trung bình trong nghiên cứu của chúng tôi là 49,6 $\pm 9,6$ tuổi, thấp nhất là 28 tuổi, cao nhất là 68 tuổi. Nhóm tuổi thường gặp từ 50-59 tuổi, chiếm 38,5\%.

Giai đoạn bệnh: Trong 52 BN nghiên cứu của chúng tôi, phần lớn bệnh nhân ở giai đoạn III $(96,1 \%)$, trong đó đa số BN ở giai đoạn IIIA, chiếm tỷ lệ $69,2 \%$. Giai đoạn IIIB, IIIC lần lượt là $17,3 \%$ và $9,6 \%$. Có 2 BN ở giai đoạn IIB chiếm 3,9\%.

Loại mô bệnh học và độ mô học: Trong nghiên cứu của chúng tôi, ung thư biểu mô xâm nhập tip NST hay gặp nhất chiếm đến 96,2\%, thể tiểu thùy và thể dị sản vảy chỉ gặp ở 1,9\%. Không có trường hợp nào thể tủy hoặc thể nhày. Độ mô học 2 hay gặp nhất với tỷ lệ $73,1 \%$, tiếp đển là độ 3 chiếm $16,4 \%$, độ 1 chiếm tỉ lệ ít nhất với 6 BN chiếm 11,5\%.

Phân loại dưới nhóm sinh học phân tử theo St Gallen: nhóm luminal B/Her2 âm tính là nhóm hay gặp nhất, chiếm tỉ lệ $42.3 \%$, sau đó đến nhóm Her 2 dương tính chiếm 25\%.

Kết quả điêu trị: Sau 8 đợt điều trị hóa chất, tỉ lệ đáp ứng toàn bộ trên lâm sàng là $98,1 \%$, trong đó ĐƯHT tăng lên tới $26,9 \%$, tỉ lệ ĐƯMP là $71,2 \%$. Kết quả này tương đương với nghiên cứu của Nguyễn Thị Thủy sau 8 chu kỳ hóa chất ${ }^{7}$. Sau điều trị hóa chất bổ trợ trước, tất cả BN của chúng tôi đều được chuyển mổ (phẫu thuật cắt tuyến vú triệt căn biến đổi). Sau mổ 11 $\mathrm{BN}$ hoàn toàn không còn tổ chức ung thư trên bệnh phẩm u vú và hạch nách (chiếm $21,2 \%$ ), có 4 người bệnh còn tổ chức ung thư tại chố (chiếm 7,6\%). Tỷ lệ đạt pCR (nhóm 1 và nhóm 2 theo Chevallier) là $28,8 \%$. Kết quả này cao hơn so với nghiên cứu của Nguyễn Thị Thủy: tỉ lệ pCR đạt $18,6 \% \%^{7}$. Có sự khác biệt này có thể giải thích do Nguyễn Thị Thủy sử dụng phác đồ 4AC4 Palitacel cho nhóm $B N$ nghiên cứu và đánh giá
pCR chỉ bao gồm nhóm 1 theo phân loại của Chevallier (nhóm 1: 18,6\% và nhóm 2: 5,1\%). Hai thử nghiệm lâm sàng lớn phase III chỉ ra sự tăng đáng kể của pCR khi thêm Docetacel vào sau 4 chu kỳ nền tảng Anthracyclin so với điều trị 4 chu kỳ này đơn thuân: nghiên cứu của Aberdeen ${ }^{8}$ đạt $p C R 34 \%$ so với $16 \%(p=0.04)$ và nghiên cứu NSABP-B $27^{9}$ tî lê pCR đat $26 \%$ thay vì $14 \%$ $(p<0.001)$. Trong thử nghiệm lâm sàng phase III E1199 trên 4954 bệnh nhân ung thư vú giai đoạn II và III đánh giá tác dụng của loại Taxan và chu kỳ của chúng cho thây sau khi điều trị 4 chu kỳ $\mathrm{AC}$, phác đồ tiếp theo chứa Paclitacel hàng tuần và Docetacel mối 3 tuần làm tăng đáng kể DFS và tăng nhẹ OS so với phác đồ có Paclitacel 3 tuần một lần và Docetacel hàng tuần.

Độc tính: Trong 52 bệnh nhân có 1 bệnh nhân phải dừng điều trị chu kỳ Docetacel cuối cùng do Viêm phổi. Tỉ lệ hạ bạch cầu và bạch cầu đa nhân trung tính thường gặp là độ 1,2 . Ha bach cầu đa nhân trung tính độ 3,4 là 6,7 và $1,2 \%$ trên tổng số 415 chu kỳ. Độc tính hạ huyết sắc tố cũng thường gặp ở đô̂ 1 .

Tỷ lệ nôn và chán ăn vẫn hay gặp, chủ yếu mức độ nhẹ. Phần lớn bệnh nhân rụng tóc gần hết hoặc toàn bộ. Ngoài ra không ghi nhận độc tính lên tim mạch ở những bệnh nhân trong nghiên cứu.

\section{KẾT LUÂNN}

1. Đặc điểm lâm sàng, cận lâm sàng của bệnh nhân nghiên cứu

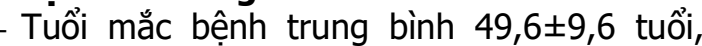
cao nhất 68 tuổi, thấp nhất 28 tuổi.

- Tỷ lệ giai đoạn bệnh IIb, IIIA, IIIB, IIIC tương ứng là $3,9 \%, 69,2 \%, 17,3 \%$ và $9,6 \%$.

96,2\% BN có thể mô bệnh học là carcinoma xâm nhập típ NST. Đa số BN có độ mô học II, chiếm $73,1 \%$

- Trong nhóm nghiên cứu của chúng tôi nhóm Luminal B/Her2 âm tính hay gặp nhất chiếm $42,3 \%$, sau đó là nhóm Her 2 dương tính chiếm $25 \%$.

2. Kết quả hóa trị bổ trợ trước và tác dụng không mong muốn của phác đồ 4AC-4T

\section{1. Đáp ứng}

- Tî lệ người bệnh đáp ứng hoàn toàn trên lâm sàng tăng từ $5,8 \%$ sau 4 đợt điều trị hóa chất lên 26,9\% sau 8 đợt điều trị hóa chất.

- Đáp ứng hoàn toàn trên mô bệnh học đạt 28,8\% (nhóm 1 và 2 theo phân loại Chevallier).

\subsection{Tác dụng không mong muốn}

- Tỷ lệ số chu kỳ hạ BCĐNTT độ 3 và độ 4 tương ứng là $6,7 \%$ và $1,2 \%$ trong tổng số 415 
chu kỳ điêu trị.

- Nôn và chán ăn thường gặp ở độ 1 , 2. Độc tính trên gan biểu hiện tăng men gan cũng thường chỉ gặp ở độ 1, 2.

- Hầu hết BN trong nghiên cứu đều bị rụng

tóc, lến tới 86,5\% rụng tóc gân hết hoặc toàn bộ

- Không có trường hợp nào độc tính trên tim.

\section{TÀI LIÊU THAM KHẢO}

1. 20-Breast-fact-sheet.pdf. Accessed June 14, 2021. https://gco.iarc.fr/ today/data/factsheets/ cancers/20-Breast-fact-sheet.pdf

2. 704-viet-nam-fact-sheets.pdf. https://gco.iarc.fr/ today/data/ factsheets/ populations/704-viet-nam-fact-sheets.pdf

3. Valero null, Buzdar null, Hortobagyi null. Locally Advanced Breast Cancer. The Oncologist. 1996;1(1 \& 2):8-17.

4. Lee MC, Newman LA. Management of patients with locally advanced breast cancer. Surg Clin North Am. 2007;87(2):379-398, ix. doi:10.1016/j.suc.2007.01.012
5. Eisenhauer EA, Therasse P, Bogaerts J, et al. New response evaluation criteria in solid tumours: revised RECIST guideline (version 1.1). Eur j Cancer Oxf Engl 1990. 2009;45(2):228-247. doi:10.1016/j.ejca.2008.10.026

6. Guarneri V, Broglio $K$, Kau S-W, et al. Prognostic value of pathologic complete response after primary chemotherapy in relation to hormone receptor status and other factors. J Clin Oncol Off J Am Soc Clin Oncol. 2006;24(7):1037-1044. doi:10, 1200/JCO.2005.02.6914

7. Nguyê̂n Thi Thưy. Đánh giá kêt quả hóa tri bổ trơ trước phác đồ $4 A C-4 T$ trên bênh nhân ung thư vú giai đoan III không mổ đước. Published online 2016.

8. Hutcheon AW, Heys SD, Sarkar TK, Aberdeen Breast Group. Neoadjuvant docetaxel in locally advanced breast cancer. Breast Cancer Res Treat. 2003;79 Suppl 1:S19-24. doi:10.1023/ a:1024333725148

9. Preoperative Doxorubicin Plus Cyclophosphamide Followed by Preoperative or Postoperative Docetaxel. Accessed June 15, 2021. https://www.cancernetwork.com/view/preoperativ e-doxorubicin-plus-cyclophosphamide-followedpreoperative-or-postoperative-docetaxel

\title{
MỐI LIÊN QUAN GIỮA NỒNG Độ SẮT HUYẾT THANH, FERRITIN VỚI BÊNNH LÝ ĐÁI THÁO ĐƯỜNG THAI KỲ
}

\author{
Võ Thị Hải Dương1, Võ Minh Tuấn ${ }^{1}$, Phạm Trung Hà2
}

\section{TÓM TẮT}

Đặt vấn đề: Sắt là một trong những vi chất cần thiết cho các chức năng tế bào để có thể đảm bảo sư phát triển bình thường của thai nhi. Tuy nhiên ngoài những tác động tích cực, việc quá tải sắt trong cơ thể gây ra stress oxy hóa, có thể dẫn đến tình trạng đề kháng insulin, cũng như suy giảm chức năng tể bào $\beta$ của tuyến tụy. Điều này có thể trở thành con dao 2 lưỡi trong thai kỳ. Muc tiêu nghiên cứu: Xác định mối liên quan giữa nổng độ sắt huyết thanh, ferritin với bênh lý ĐTĐTK. Phướng pháp nghiên cứu: Nghiên cứu bệnh - chứng (1:2) trên 192 thai phụ có tuổi thai từ $24-28$ tuần đến khám tại Bênh viên Phụ sản Quốc tế Sài Gòn trong khoảng thời gian từ tháng 12/2020 đến tháng 04/2021 (trong đó 64 thai phụ chẩn đoán có ĐTĐTK và 128 thai phụ không có ĐTĐTK theo tiêu chuẩn của Hiệp hội đái tháo đường Hoa Kỳ năm 2018). Mẫu máu lúc đói trong nghiệm pháp dung nạp glucose $75 \mathrm{~g}$ được sử dụng để định lượng sắt huyết thanh và ferritin. Kết quả: Nhóm thai phụ có nồng độ ferritin $\geq 30 \mathrm{ng} / \mathrm{mL}$ có nguy cơ mắc ĐTĐTK gấp 5,04 lần so với thai phụ có nồng độ

${ }^{1}$ Dai hoc Y Dươc TP.HCM

²Bệnh viện Phụ sản Quốc tế Sài Gòn

Chịu trách nhiệm chính: Võ Minh Tuấn

Email: vominhtuan@ump.edu.vn

Ngày nhận bài: 12.4.2021

Ngày phản biên khoa hoc: 25.5 .2021

Ngày duyệt bài: 14.6.2021 ferritin < $15 \mathrm{ng} / \mathrm{mL}, \mathrm{p}<0,05$. Kết luận: Qua kết quả nghiên cứu chúng tôi không tìm thấy mối liên quan giữa nồng độ sắt huyết thanh và bệnh lý ĐTĐTK, nồng độ ferritin cao có liên quan đến nguy cơ mắc ĐTĐTK.

Tư khóa: Đái tháo đường thai kỳ, sắt huyết thanh, ferritin, nghiệm pháp dung nạp glucose $75 g-2 h$.

\section{SUMMARY \\ CORRELATION BETWEEN SERUM IRON, FERRITIN LEVELS AND RISK OF GESTATIONAL DIABETES MELLITUS}

Background: Iron is one of the micronutrients that necessary for cellular functions to ensure the normal development of the fetus. However, in addition to the positive effects, iron overload in the body causes oxidative stress, which can lead to insulin resistance, as well as reduce function of pancreatic $\beta$ cells. This becomes a double-edged sword in pregnancy. Objective: The aim of the study was to determine the relationship between serum iron and ferritin levels with GDM. Methods: A case control study (ratio 1:2) was conducted with 192 pregnant women from 24 to 28 weeks of gestation who have antenatal care at SaiGon International OB-GYN Hospital, from December 2020 to April 2021 (64 pregnant women with GDM as cases \& 128 pregnant women without GDM as controls according to diagnostic criteria of the American Diabetes Association, 2018). Venous blood samples in 75-g 2hour oral glucose tolerance test were used for estimation of serum iron and ferritin. Result: Group 